\title{
Design of tools to reduce the risk level of work postures at warping station
}

Indira Kusuma Wardani*, Irwan Iftadi, Rahmaniyah Dwi Astuti

Department of Industrial Engineering, Universitas Sebelas Maret, Jalan Ir.Sutami No. 36A, Surakarta, Jawa Tengah 57126, Indonesia

\section{Article history: \\ Received: January 16, 2020 \\ Revised: June 19, 2020 \\ Accepted: June 24, 2020 \\ Keywords: \\ Product design \\ REBA \\ Pahl and beitz method \\ Trolley}

ARTICLE INFORMATION

\section{A B S T T R A C T}

Based on the REBA analysis, there is a risky operator work postures in the warping work station at PT. Iskandar Indah Printing Textile because they do not use work tools. The assessment of the level of work posture risk by the REBA method gets the result that the highest work element with a final score of 10 is obtained by taking warp yarn at the warping station. This study aims to produce a design tool to reduce the level of work posture risk in warping work station operators. Then the design of tools was carried out by the Pahl and Beitz method to produce three alternative product design concepts. Based on the three ideas, the best plan is chosen by using an Engineering Design Selection, and the result is the second design concept. The selected design is an adjustable trolley with a vertical screw drive system that is comfortable to use and does not cause a bending position on the operator because it has a trolley plate that can be adjusted in height as needed. The use of the trolley causes a decrease in the level of work posture risk from a high-risk level to a small risk level with a final score of 10 to 3 .

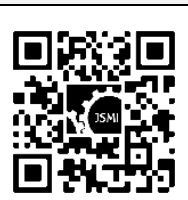

This is an open-access article under the CC-BY-NC-SA license.

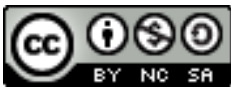

Indira Kusuma Wardani

E-mail: indiraksma@gmail.com

(C) 2020 Some rights reserved

\section{INTRODUCTION}

In the industrial world, material handling work is still done manually until now. The work is known as Manual Material Handling (MMH). $\mathrm{MMH}$, which consists of pushing, lifting, lowering, carrying, and pulling, is the primary source of employee complaints in the industry [1]. The selection of humans as workers in handling material has an advantage that is being able to adjust movement to facilitate the transfer of loads in tight spaces and irregular work. However, MMH activities have some risks when applied to the wrong working attitude, working aids, and inadequate working environment conditions [2]. MMH activity, which results in bending and turning positions, should be reduced or, if possible, corrected because this attitude is prone to disorders of the musculoskeletal system [3].

Work posture is the link between the dimensions of the worker's body with the aspects of the tool at his workplace [4]. Strange work postures, lifting movements, forceful movements, and high-speed manual work contribute to musculoskeletal disorders [5]. Musculoskeletal complaints are complaints on the part of the skeletal muscle that is felt by someone ranging from mild to severe complaints [6]. One study of 
female workers in a wool textile factory [7] found that pain and fatigue were the main problems for women in the spinning section. The study recommends that ergonomic factors, such as good rest and periods of rest, can restore musculoskeletal symptoms. The highest disturbance is reported to occur in the lower back, knees, and upper back, as well as recommendations made to eliminate awkward postures and manual handling of weights [8]. It is necessary to research work posture [9] to develop the concept of designing a work environment so that the level of postural stress in labor is low [10]. The design of the work environment is expected to increase productivity, reduce the level of fatigue, and provide comfort at work [11].

PT. Iskandar Indah Printing Textile is a textile company that processes yarn raw materials into raw fabrics (gray), which are then processed into batik printing. PT. Iskandar Indah Printing Textile has two departments, namely the weaving department and printing department. In the weaving department, there are six workstations, namely warping station, sheathing station, racing station, pallet station, weaving station, and finishing station. Some workers complained about work disruptions experienced due to improper manual material handling activities. Wrong working attitudes and inadequate aids cause workers to experience health problems.

At the initial observation, an assessment of the level of work posture risk was carried out at all workstations using the REBA (Rapid Entire Body Assessment) method. The REBA method is a method in the field of ergonomics that is used to quickly assess the work position or posture of an operator's neck, back, arms, wrists, and ankles. This method is also influenced by coupling factors, external loads, and labor activity [12]. The REBA method was chosen because it can be used to assess work postures of upper and lower body parts and can assess dynamic work (experiencing displacement).

The following are the results of the work posture assessment using the Rapid Entire Body Assessment (REBA) of all operators working in the weaving department of PT. Iskandar Indah Printing Textile (Fig. 1). From this diagram, it can be seen that $18 \%$ of the 61 work elements in the weaving department have a high risk of work posture, so repairs must be immediately carried out. One work element that has a high level of work posture risk is taking warp yarn rolls at warping stations with REBA calculation value 10 . A high REBA value is caused by the operator making warp yarn rolls placed on the floor without tools so that workers in standing position must bend with an angle of more than $60^{\circ}$.

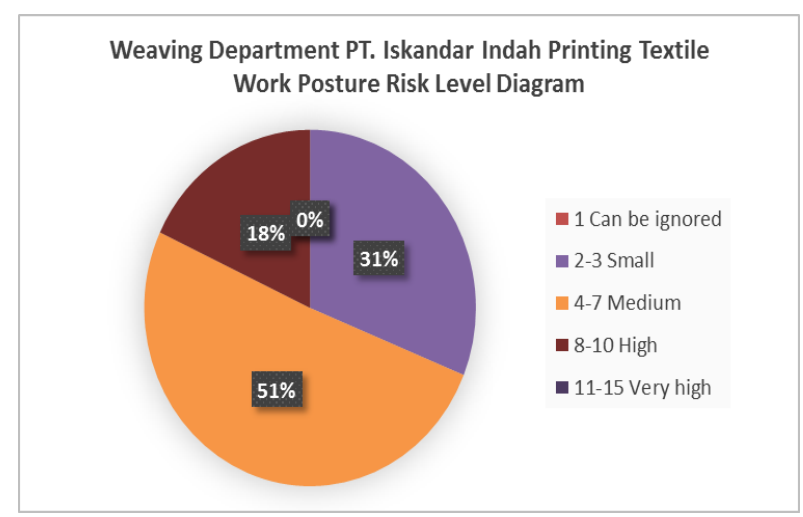

Fig. 1. Work posture risk assessment results

When picking up the warp yarn rolls on the floor, the workers must bend and twist so that they cause pain in the back and waist. In addition, the age factor also affects the operator's performance because the percentage of individuals over the age of 45 years as much as $57.6 \%$ more easily experience fatigue compared to individuals under the age of 45 years [13]. It can have a negative impact on companies and workers, such as reduced work productivity and the emergence of pain in workers, which are temporary or permanent.

According to the problems that have been explained, this study aims to produce a design tool to reduce the level of operator's work posture risk in warping station PT. Iskandar Indah Printing Textile. The design of tools to carry warp yarn sacks is carried out using the Pahl and Beitz methods.

\section{RESEARCH METHODS}

This research was conducted at the weaving department of PT. Iskandar Indah Printing Textile. Stages of research refer to the concepts developed by Pahl and Beitz in the design of a product. In previous studies, Pahl and Beitz's methods are also used to design products [14], without paying attention to aspects of ergonomics. This study tries to develop products based on ergonomics principles to improve the convenience of users. The stages of the research consist of observation, risk level analysis, planning and task explanation 
stages, product concept design stages, product design stages, and product detail design stages [15] (Fig. 2).

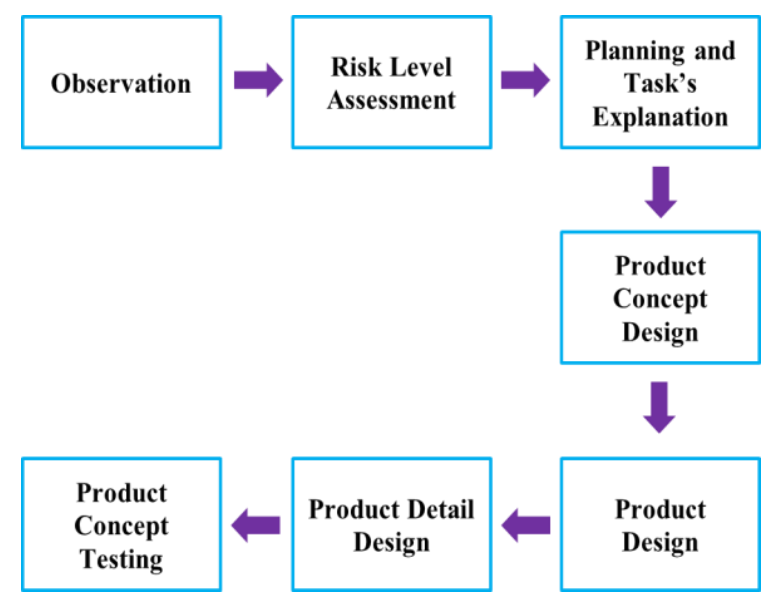

Fig. 2. Research steps

Observations were made while the operator was working at all workstations. The result of representation is a provisional conjecture that there are some risky work postures and work aids that do not meet ergonomic aspects. Therefore, it is necessary to conduct a risk level analysis as a preliminary study to corroborate the provisional allegations obtained during observation.

Risk level analysis is carried out using the REBA (Rapid Entire Body Assessment) method. Evaluation using this method consists of several stages, namely taking data by photographing the worker's body posture during work activities, determining the angle of each worker's body, and calculating the score of movement of body parts based on the angle formed [16]. From the final REBA score, the risk level in musculoskeletal risk can be determined, and then the work element with the highest level of work posture risk is chosen. Improvements were made to the work element with a proposed design tool to reduce the risk of operator work posture [17].

Next is the design of work aids. The first stage is the planning and explanation of tasks which aim to develop technical specifications that have specific functions and certain characteristics that meet the needs of the operator. At this stage, identification of problems, and customer needs (demand or wishes) is carried out to obtain appropriate technical specifications. The identification is carried out through direct and informal interviews with operators at selected stations.
The second stage is the design of product concepts that aim to determine the product concept that can meet the requirements in the technical specifications that have been established in the previous stage. This stage carried out assessing the structure of product functions, identifying the principle of solutions, and assessing alternative products [18]. Determination of the product function structure is arranged to start from the overall function of the product and then broken down into several sub-functions that are described with block diagrams. Determination of the principle of solutions and the commitment of alternative products is done by using a morphological chart [19].

The third stage is the design of product designs that aim to make product designs based on predetermined concepts so that the product can be used in accordance with its function. The product concept that has been determined consists of several selected alternatives in accordance with the specifications and features of the product. At this stage, product design is made and product design is assessed. The process of making a product design is done by using a Solidwork application based on alternative design concepts that have been determined in the previous stage. Product design assessment is done by the Engineering Design Selection or decision matrix [20]. Each idea of a tool is compared using the specified criteria, then the scores of each idea are added together so that a selected design with the highest score will be produced.

The product detail design stage aims to design product details in the product design that has been previously selected. First, determine the dimensions of product design based on the worker's anthropometric data in order to work safely and comfortably [21]. Furthermore, it is explained about the product components and their constituent materials, which are described in the Bill of Materials (BOM). It also revealed the estimated cost of manufacturing products consisting of material costs and labor costs.

The product concept testing phase aims to predict the success of selected product designs. Testing is done using the Jack software and REBA method. In Jack's software, human animation is arranged according to predetermined anthropometric data so that an operator's posture will be obtained when using aids. Based on the posture description, the work risk level is calculated using REBA so that the calculation results will be 
collected after the use of assistive devices. The final step is to compare the level of risk of work postures before and after using tools. The design of an instrument is said to be successful if it has decreased the level of work risk after using the device.

\section{RESULTS AND DISCUSSION}

Observations were made at six work stations in the weaving department of PT. Iskandar Indah Printing Textile, namely warping stations, sheathing stations, racing stations, pallet stations, weaving stations, and finishing stations. The results of observations during the observation process are found in Table 1.

Table 1. Observation results

\begin{tabular}{|c|c|}
\hline No. & Observation results \\
\hline 1. & $\begin{array}{l}\text { There is some risky material handling } \\
\text { manual work activities. }\end{array}$ \\
\hline 2. & $\begin{array}{l}\text { Provisional allegations of some work } \\
\text { postures that have a high level of work risk } \\
\text { at the warping station. }\end{array}$ \\
\hline 3. & $\begin{array}{l}\text { Provisional allegations of work aids that } \\
\text { do not meet the ergonomic aspects of the } \\
\text { warping station. }\end{array}$ \\
\hline
\end{tabular}

\subsection{Risk level analysis}

Risk level analysis is carried out using the Rapid Entire Body Assessment (REBA) method on all elements of the work. In the weaving department, six stations are consisting of 61 work elements. The assessment is done by taking a video/picture of one worker in each work element. Based on this assessment, the results show that the work element taking warp yarn rolls at warping stations has the highest risk level. The figure of operator work posture on the work element, making warp yarn rolls, can be seen in Fig. 3 .

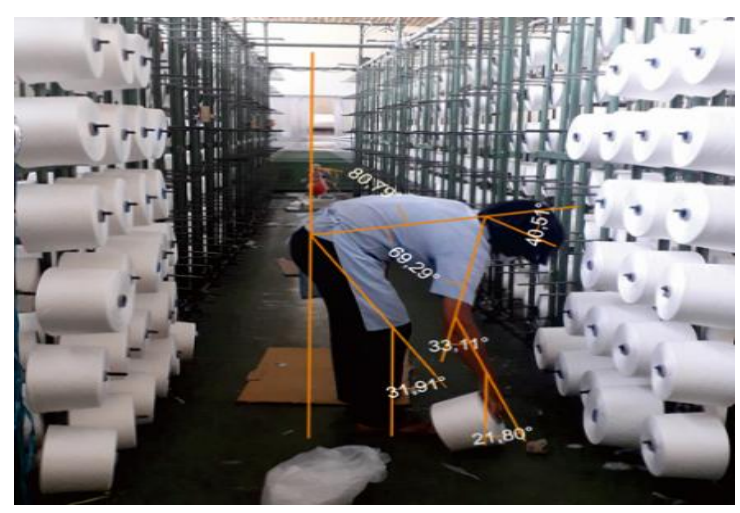

Fig. 3. Withdrawal of work element angle

Calculation with the REBA method (Table 2) obtains a final score of 10 with a high level of risk, so improvements must be made immediately to reduce the risk of work posture.

Table 2. Calculation results with REBA method

\begin{tabular}{cccc}
\hline $\begin{array}{c}\text { Group A } \\
\text { Score }\end{array}$ & $\begin{array}{c}\text { Group B } \\
\text { Score }\end{array}$ & $\begin{array}{c}\text { Activity } \\
\text { Score }\end{array}$ & $\begin{array}{c}\text { Final } \\
\text { Score }\end{array}$ \\
\hline 7 & 5 & 1 & 10 \\
\hline
\end{tabular}

\subsection{Planning and task's explanation stage}

Interviews were conducted directly with the two operators at the warping station to obtain information in the form of complaints that were felt while working and expectations for future improvement. The results of the interview can be seen in Table 3. From the results of the interview, a technical specification was then arranged through a discussion process with a product design expert. Preparation of technical specifications tailored to the needs that must be met by the product (demand) and the wishes of the user (requests) (Table 4).

Table 3. Interview Results

\begin{tabular}{cl}
\hline No. & \multicolumn{1}{c}{ Interview results } \\
\hline 1. & Workers feel tired because they have to go back and forth $15-30$ times to take a sack filled with \\
2. & Warp threads. \\
When taking sacks, workers can only carry one sack with a weight of $6 \mathrm{~kg} /$ sack to the rack \\
w. Where the roll is placed. \\
Workers have to bend around $150-250$ times when taking rolls of warp thread removed from \\
the sack to be installed on the rack. \\
5. Workers often feel pain in the back. \\
6. Workers want aids to bring warp bags of warp threads. \\
7. Workers want tools that are easy to use.
\end{tabular}


Table 4. Technical specifications

\begin{tabular}{|c|c|c|c|}
\hline Parameter & Demand (D) & Wishes (W) & Technical specifications \\
\hline Energy & $\sqrt{ }$ & & Using kinetic energy (push/pull). \\
\hline \multirow{4}{*}{ Operation } & $\sqrt{ }$ & & Easy to operate. \\
\hline & $\sqrt{ }$ & & Operation is manual. \\
\hline & $\sqrt{ }$ & & Use four wheels. \\
\hline & & $\sqrt{ }$ & Safe and environment friendly. \\
\hline Maintenance & & $\sqrt{ }$ & Easy to maintain and repair if damaged. \\
\hline \multirow[t]{4}{*}{ Manufacture } & $\sqrt{ }$ & & Simple construction / component. \\
\hline & $\sqrt{ }$ & & Strong and durable material. \\
\hline & $\sqrt{ }$ & & Easy to make/do. \\
\hline & & $\sqrt{ }$ & Affordable manufacturing costs. \\
\hline \multirow[t]{2}{*}{ Ergonomics } & $\sqrt{ }$ & & $\begin{array}{l}\text { The dimensions of the tool corresponding to the } \\
\text { dimensions of the operator's body. }\end{array}$ \\
\hline & $\sqrt{ }$ & & Can reduce the bending operator position. \\
\hline Capacity & $\sqrt{ }$ & & Can carry more spools of yarn. \\
\hline
\end{tabular}

\subsection{Product concept design stage}

The steps at this stage are to determine the structure of the product's function, establish the principle of the solution, and discover the product alternatives. Determination of product function structure based on technical specifications in the previous stage. The product function structure is organized, starting from the overall product function and broken down into several subfunctions (Fig. 4 and Fig. 5).

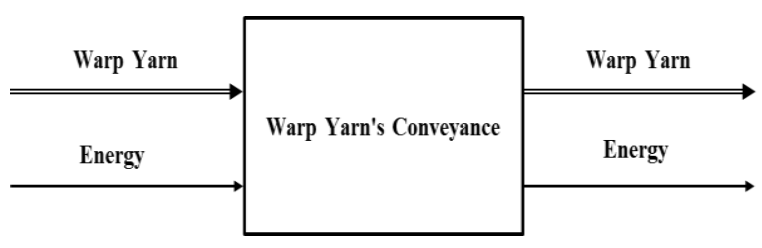

Fig. 4. Overall product function diagram

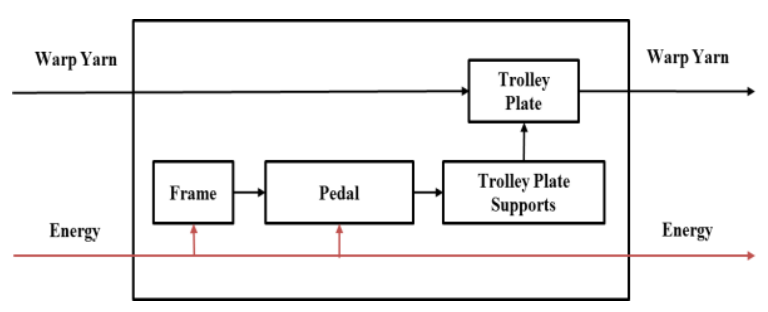

Fig. 5. Product sub function diagram

The determination of the principle of the solution is based on the predetermined product sub-functions. Combining the policy of solutions with product sub-functions is done using a morphological chart (Table 5).
Table 5. Principle of solution

\begin{tabular}{|c|c|c|c|c|}
\hline \multicolumn{2}{|c|}{ Sub function } & I & II & III \\
\hline 1 & $\begin{array}{l}\text { Cross- } \\
\text { section } \\
\text { drive } \\
\text { system }\end{array}$ & Hydraulic & $\begin{array}{l}\text { Vertical } \\
\text { screw }\end{array}$ & \multirow[t]{2}{*}{$\begin{array}{l}\text { Linkage } \\
\text { screw }\end{array}$} \\
\hline 2 & $\begin{array}{l}\text { Operating } \\
\text { system }\end{array}$ & Manual & $\begin{array}{l}\text { Semi- } \\
\text { automatic }\end{array}$ & \\
\hline 3 & $\begin{array}{l}\text { Operator } \\
\text { handling }\end{array}$ & $\begin{array}{l}\text { Rotate } \\
\text { crank }\end{array}$ & $\begin{array}{l}\text { Foot } \\
\text { pedal }\end{array}$ & \multirow{3}{*}{ Plastic } \\
\hline 4 & $\begin{array}{l}\text { Cross- } \\
\text { section } \\
\text { material }\end{array}$ & Wood & Iron & \\
\hline 5 & $\begin{array}{l}\text { Frame } \\
\text { material }\end{array}$ & Wood & Iron & \\
\hline
\end{tabular}

The determination of product alternatives is based on several predetermined combinations on the morphological chart (Table 6). The alternative products chosen were three alternatives in accordance with the three types of drive systems used, namely hydraulic, vertical screw, and linkage screw.

Here are the three alternative concepts that are changed into the mathematical form:
a. Alternative 1 (red) : S11 + S22 + S31 + S41 + S52
b. Alternative 2 (orange): $\mathrm{S} 12+\mathrm{S} 21+\mathrm{S} 31+$ $\mathrm{S} 42+\mathrm{S} 52$
c. Alternative 3 (blue) : $\mathrm{S} 13+\mathrm{S} 21+$ $\mathrm{S} 32+\mathrm{S} 43+\mathrm{S} 51$ 
Table 6. Alternative products

\begin{tabular}{|c|c|c|c|c|}
\hline \multicolumn{2}{|c|}{$\begin{array}{l}\text { Principle of solution } \\
\text { Sub function }\end{array}$} & I & II & III \\
\hline 1 & $\begin{array}{l}\text { Cross-section } \\
\text { drive system }\end{array}$ & Hydraulic & Vertical & $\begin{array}{l}\text { Linkage } \\
\text { screw }\end{array}$ \\
\hline 2 & $\begin{array}{l}\text { Operating } \\
\text { system }\end{array}$ & & & \\
\hline 3 & $\begin{array}{l}\text { Operator } \\
\text { handling }\end{array}$ & $\begin{array}{l}\text { Rotate } \\
\text { crank }\end{array}$ & & \\
\hline 4 & $\begin{array}{l}\text { Cross-section } \\
\text { material }\end{array}$ & Wood & & Plastic \\
\hline 5 & Frame material & & & \\
\hline
\end{tabular}

\subsection{Product concept design stage}

The product design is designed by considering the principles of ergonomics in handling, loading, and unloading materials [22]. The product design is done based on the three alternative concepts that have been determined in the previous stage. The following is the third alternative design concept of product design.

\section{a. The first product design concepts}

The first alternative is a trolley with an adjustable system using a hydraulic drive system that is operated semi-automatically. Hydraulic procurement costs around $\mathrm{Rp}$. $1,000,000$ sourced from tokopedia.com and its components are more complicated because it uses a motor system. The operation uses a foot pedal that will move the cross-section up and down with the operator standing upright so that it does not result in a bending position on the operator. The material used to arrange the trolley frame is iron, the material was chosen because it is strong and durable, so it is appropriate to be used as a frame. While the material making up the trolley cross-section is wood, the material is quite strong but not durable because it can rot. The wood material was used as a cross-section to make the trolley lighter because it was heavy enough due to using hydraulics. The cross-section is designed to be able to carry 1-3 sacks of warp threads. One sack has a size of $66 \mathrm{~cm} \times 88 \mathrm{~cm}$ with a weight of $6 \mathrm{~kg} / \mathrm{sack}$. The handle used is round steel so that it is comfortable and makes it easy for the operator to hold. The design of this trolley is quite easy in terms of maintenance, but if it is damaged, especially in the hydraulic part, it is more complicated to repair. (Fig. 6).

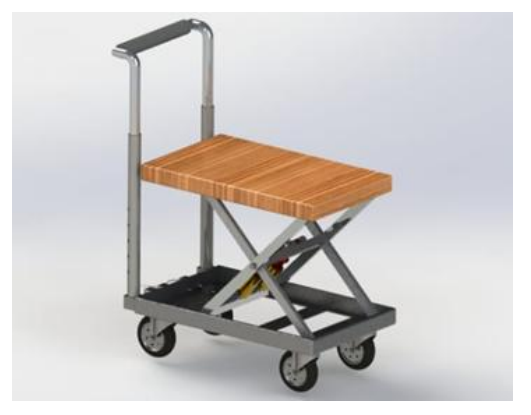

Fig. 6. The first product design

\section{b. The second product design concepts}

The second alternative is an adjustable system trolley using a manually operated vertical screw drive system. The cost of procuring vertical screws is around Rp. 135,000 and simpler components because it uses a manual system. The operation uses a rotary crank that will raise the cross-section with the operator standing upright so that it does not result in a bending position on the operator. The material used to arrange the trolley frame is iron, the material was chosen because it is sturdy and durable, so it is appropriate to be used as a frame. While the material making up the trolley is an iron plate, the material was chosen because it is sturdy and durable. The crosssection is designed to be able to carry 1-3 sacks of warp threads. One sack has a size of 66 $\mathrm{cm} \times 88 \mathrm{~cm}$ with a weight of $6 \mathrm{~kg} / \mathrm{sack}$. The handle used is round steel so that it is comfortable and makes it easy for the operator to hold. The height of the handle is also designed according to the operator's anthropometry so that convenient to use. This trolley design is quite easy in terms of maintenance and repairs if damaged (Fig. 7).

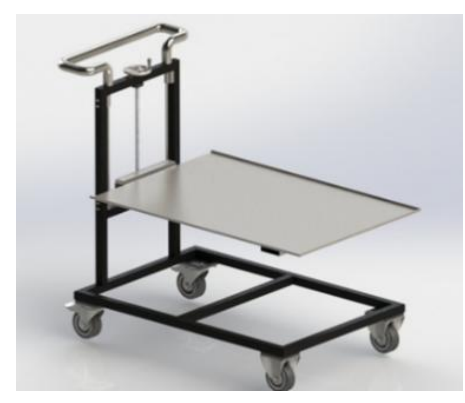

Fig. 7. The second product design 


\section{c. The third product design concepts}

The third alternative is an adjustable system trolley using a manually operated linkage screw drive system. Linkage screw procurement costs around Rp. 98,000 sourced from tokopedia.com and its components are simpler because it uses a manual system. The operation uses a rotary crank that will raise the cross-section with the operator bending position because his position is at the bottom of the cross-section board. The material used to arrange the trolley frame is iron, the material was chosen because it is strong and durable, so it is appropriate to be used as a frame. While the material making up the trolley is an iron plate, the material was chosen because it is sturdy and durable. The cross-section is designed to be able to carry 1-3 sacks of warp threads. One bag has a size of $66 \mathrm{~cm} \times 88 \mathrm{~cm}$ with a weight of $6 \mathrm{~kg} / \mathrm{sack}$. The height of the handle is designed according to the anthropometry of the operator, but the material used is square steel, so it is less comfortable and makes it easier for the operator to grasp. This trolley design is quite easy in terms of maintenance and repairs if damaged (Fig. 8).

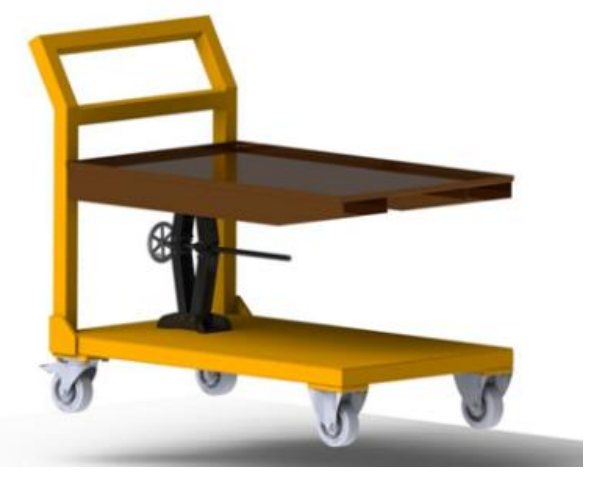

Fig. 8. The third product design

The product design assessment is then performed by comparing the three trolley design concepts that have been made with several selection criteria using a decision matrix (Table 7). The determination of design selection and assessment criteria is carried out by discussion with design experts. Based on the trolley design assessment table, the total score of concept 1 was 81.14 , idea 2 was 115.43 , and idea 3 was 95.43. The scores that have been obtained are then sorted by ranks one through three. Based on the results of the three counts, the second design concept is the concept chosen with the highest score.

Table 7. Evaluation of the three trolley design concepts

\begin{tabular}{|c|c|c|c|c|c|c|c|c|}
\hline \multirow[t]{2}{*}{ No. } & \multirow[t]{2}{*}{ Criteria } & \multirow[t]{2}{*}{ Wt (a) } & \multicolumn{6}{|c|}{ Concept } \\
\hline & & & B & B.a & $\mathbf{C}$ & C.a & $\mathbf{D}$ & D.a \\
\hline \multirow{2}{*}{$\begin{array}{l}1 . \\
2 .\end{array}$} & Strong and durable material & 16 & 6 & 96 & 8 & 128 & 8 & 128 \\
\hline & $\begin{array}{l}\text { The cost of procuring a cross- } \\
\text { section drive system is } \\
\text { affordable }\end{array}$ & 12 & 2 & 24 & 6 & 72 & 8 & 96 \\
\hline 3. & $\begin{array}{l}\text { Reducing the bending body } \\
\text { position of the operator }\end{array}$ & 20 & 9 & 180 & 9 & 180 & 4 & 80 \\
\hline 4. & $\begin{array}{l}\text { Easy and convenient to } \\
\text { operate }\end{array}$ & 16 & 7 & 112 & 8 & 128 & 4 & 64 \\
\hline \multirow{2}{*}{$\begin{array}{l}5 . \\
6 .\end{array}$} & Easy to maintain and repair & 8 & 2 & 16 & 8 & 64 & 8 & 64 \\
\hline & $\begin{array}{l}\text { Simple constituent } \\
\text { components (not } \\
\text { complicated) }\end{array}$ & 16 & 2 & 32 & 8 & 128 & 8 & 128 \\
\hline 7. & $\begin{array}{l}\text { Able to accommodate more } \\
\text { yarn spools }\end{array}$ & 12 & 9 & 108 & 9 & 108 & 9 & 108 \\
\hline & Total & 100 & & 81.14 & & 115.43 & & 95.43 \\
\hline
\end{tabular}


The product detail design stage explained the determination of anthropometric data, product design dimensions, product design specifications, and the estimated cost of making a product. The determination of product dimensions is based on anthropometric data of two female workers who carry out the task of taking warp yarns at warping stations. Both workers have an age range of more than 45 years. Anthropometric data retrieval of the worker's body is only carried out on the dimensions of the body associated with the design process carried out.

Furthermore, the uniformity test of the anthropometric data obtained and the calculation of the percentile values of 5, 50, and 95 [23] will be used in determining the dimensions of the design. (Table 8). Determination of the dimensions of the design of the product design is done after testing the uniformity of data and calculating the value of percentiles (Table 9)..

Table 8. Test uniformity of data and percentile values $(\mathrm{cm})$

\begin{tabular}{lcccc}
\hline \multicolumn{1}{c}{ Dimension } & $\begin{array}{l}\text { Standard } \\
\text { deviation }\end{array}$ & P5 & P50 & P95 \\
\hline $\begin{array}{l}\text { Elbow height } \\
\text { stand (Tsb) }\end{array}$ & 0,7 & 92.05 & 95.5 & 98.95 \\
$\begin{array}{l}\text { Shoulder } \\
\text { width (Lb) }\end{array}$ & 2,1 & 36.05 & 39.5 & 43 \\
$\begin{array}{l}\text { The diameter } \\
\text { of the } \\
\text { handheld ring } \\
\text { (dlg) }\end{array}$ & 0.35 & 3.17 & 3.75 & 4.32 \\
\hline
\end{tabular}

Table 9. Dimensions of product design

\begin{tabular}{lc}
\hline \multicolumn{1}{c}{ Dimension } & Size $(\mathbf{c m})$ \\
\hline Trolley length & 90 \\
Trolley width & 60 \\
Trolley grip height & 93 \\
Trolley grip width & 53 \\
Trolley handle diameter & 4 \\
Length of sectional board & 70 \\
Cross section width & 60 \\
Max height of cross section board & 80.5 \\
Min height cross section & 50.5 \\
\hline
\end{tabular}

The trolley is designed with an adjustable system making it easier to transport workpieces (Fig. 9). Trolley design uses several components including bottom frame, lifter trolley, nut crew, vertical screw, wheel, bearing housing, handwheel, hex bolt, hex nut and nutsert. Determination of estimated costs consists of the material costs required and the cost of workers to make one trolley. The total cost required is $\mathrm{Rp}$ 1.374 .000

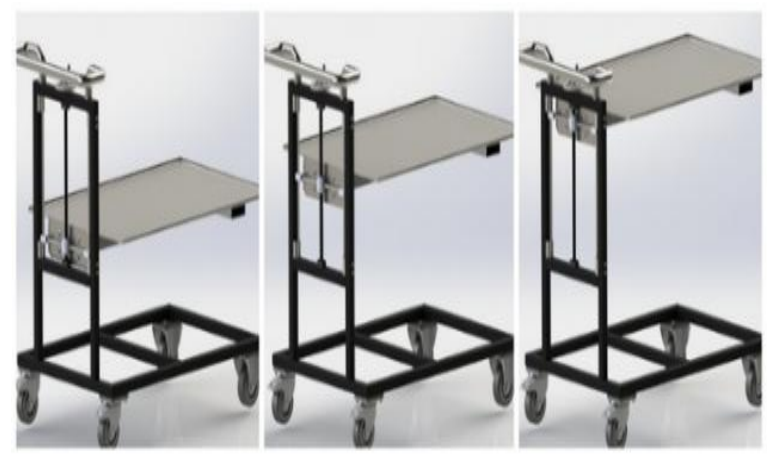

Fig. 9. Adjustable trolley design

\subsection{Product concept testing stage}

At this stage, it is explained about the successful testing of selected product designs. This success can be determined by comparing the level of risk of work postures before and after using tools. In Table 10, it can be seen that the work element encourages the trolley to get a final score of 3, and the work element takes the warp yarn rolls to get a final score of 3 . The results of the assessment have a small risk level, which means that improvements may be needed. Whereas in table 2 shows that the results of the evaluation of work elements take warp yarn rolls before using tools to get a final score of 10 . It shows that there is a decrease in risk level after the operator uses the trolley, i.e., from a high-risk level with a final score of 10 being a risk level small with a final score of 3 . The trolley design is able to fix the position of the worker's body. This change is able to ease the physical burden of workers so as to increase work productivity [24], [25]. 
Table 10. Comparison between work postures before and after using a trolley

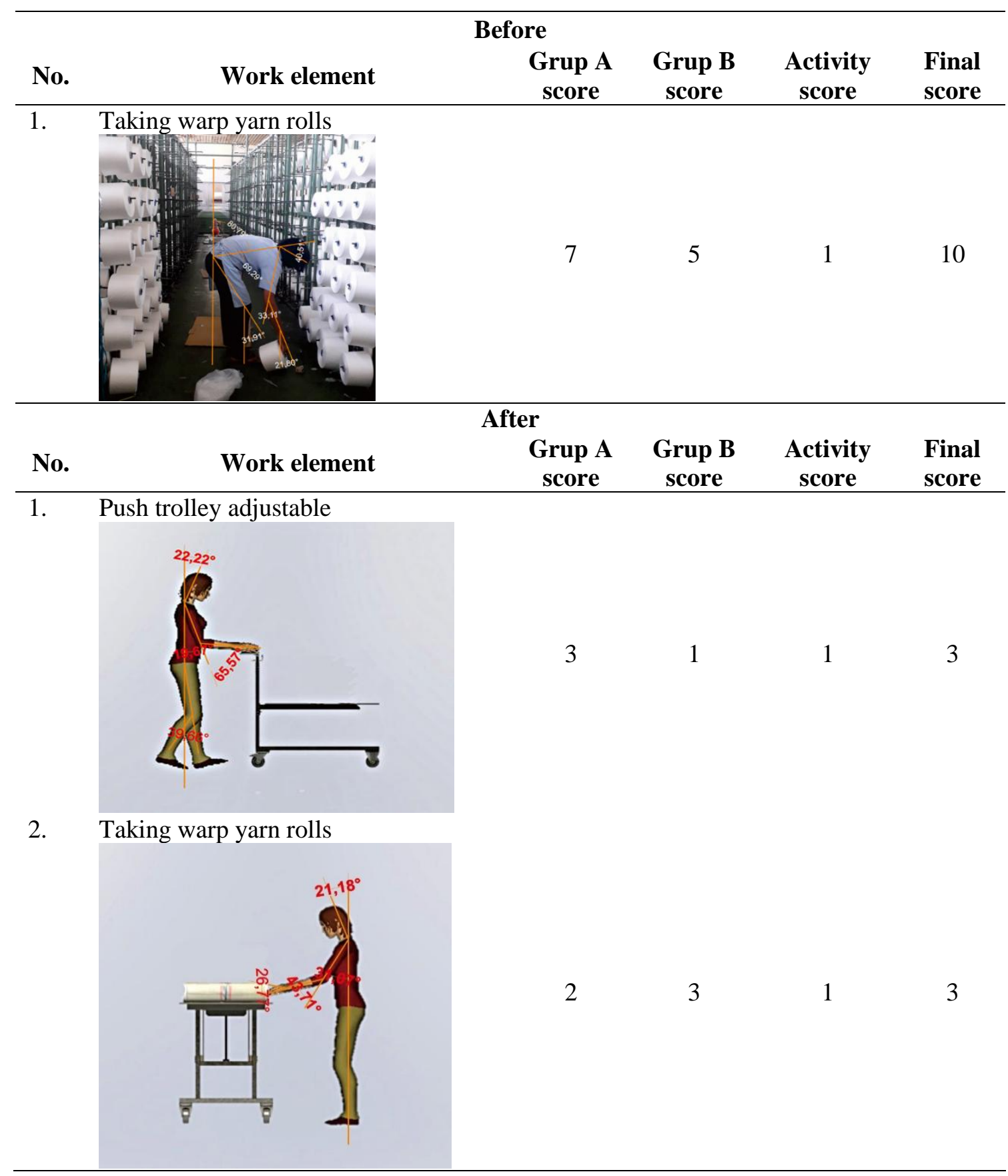

\section{CONCLUSION}

From this study, an adjustable trolley design was produced to reduce the level of work posture risk at the warping station operator at PT. Iskandar Indah Printing Textile. The advantage of the tool is that it has a cross-section that can be adjusted in height so that it does not result in a bending position when the operator is carrying out work activities. Besides, the design trolley can increase productivity at the warping station because the operator can carry three sacks at a time. In contrast, before designing, the operator can only take one bag. The use of these trolleys can also reduce the level of work risk from a score of 10 with a high-risk level to 3 with a small risk level, as evidenced through the concept testing stage. For further research, it can be done making a prototype of selected trolley adjustable design so 
that that concept testing can be done directly to related parties.

\section{REFERENCES}

[1] E. Muslimah, I. Pratiwi, and F. Rafsanjani, "Analisis manual material handling menggunakan NIOSH equation," J. Ilm. Tek. Ind., vol. 5, no. 2, pp. 53-60, 2006, available:

http://journals.ums.ac.id/index.php/jiti/arti cle/view/1566.

[2] R. D. Astuti and I. Iftadi, Analisis dan Perancangan Sistem Kerja. Deepublish, 2016, available at: Google Scholar.

[3] B. P. T. Nugroho, I. Iftadi, and T. Rochman, "Usulan Rancangan Troli Sebagai Alat Bantu Angkut Karung Gabah Dalam Rangka Perbaikan Postur Kerja di Penggilingan Padi (Studi Kasus: Penggilingan Padi di Sragen)," PERFORMA Media Ilm. Tek. Ind., vol. 12, no. 1, pp. 9-18, 2013, available: https://jurnal.uns.ac.id/performa/article/vi ew/13838.

[4] S. Pheasant and C. M. Haslegrave, Bodyspace: Anthropometry, ergonomics and the design of work. Boca Raton: CRC Press, 2018, doi: 10.1201/9781315375212.

[5] L. P. Singh, "An investigation into work postures of workers engaged in casting industry: a study in India," Asian J. Manag. Sci., vol. 1, no. 1, pp. 17-22, 2012, available:

https://www.trp.org.in/issues/an-

investigation-into-work-postures-ofworkers-engaged-in-casting-industry-astudy-in-india-2.

[6] E. Grandjean, Fitting The Task to the Man: A Textbook of Occupational Ergonomics, 4th edition. Taylor \& Francis, 1990, doi: 10.1080/00207549008942723.

[7] O. Karhu, P. Kansi, and I. Kuorinka, "Correcting working postures in industry: A practical method for analysis," Appl. Ergon., vol. 8, no. 4, pp. 199-201, Dec. 1977, doi: 10.1016/0003-6870(77)901648.

[8] S. Torp and B. E. Moen, "The effects of occupational health and safety management on work environment and health: A prospective study," Appl. Ergon., vol. 37, no. 6, pp. 775-783, Nov. 2006, doi: 10.1016/j.apergo.2005.11.005.

[9] L. P. Singh, A. Bhardwaj, K. K. Deepak, and S. Sahu, "Small \& medium Scale Casting and Forging Industry in India: an ergonomic study," Ergon. SA J. Ergon. Soc. South Africa, vol. 22, no. 1, pp. 3656, 2010, available: https://journals.co.za/content/ergosa/22/1/ EJC33288.

[10] R. Bridger, Introduction to Ergonomics, Second Edition. London: CRC Press, 2008, doi: 10.1201/9781315375212.

[11] A. Zaheer and R. Khalid, "Ergonomics: A work place realities in Pakistan," Int. Posture J. Sci. Technol., vol. 2, no. 1, pp. 1-11, 2012, available: http://journaldatabase.info/articles/ergono mics_work_plae_realities.html.

[12] S. Hignett and L. McAtamney, "Rapid Entire Body Assessment (REBA)," Appl. Ergon., vol. 31, no. 2, pp. 201-205, Apr. 2000, doi: 10.1016/S00036870(99)00039-3.

[13] A. Mentari, K. Kalsum, and U. Salmah, "Hubungan Karakteristik Pekerja dan Cara Kerja dengan Kelelahan Kerja pada Pemanen Kelapa Sawit di PT. Perkebunan Nusantara IV (PERSERO) Unit Usaha Adolina Tahun 2012," J. Lingkung. dan Keselam. Kerja, vol. 1, no. 2, pp. 42-52, 2012, available: https://jurnal.usu.ac.id/index.php/lkk/artic le/view/1327.

[14] A. Suwandi, M. Sulaiman, and E. Maulana, "Perancangan Mesin Eddy Current Separator Untuk Pemilah Sampah Logam Non-Ferrous (Studi Kasus Di Kabupaten Tegal)," in Seminar Nasional Sains dan Teknologi (SEMNASTEK), 2017, pp. 1-9, available: https://jurnal.umj.ac.id/index.php/semnast ek/article/view/1961.

[15] G. Pahl, W. Beitz, J. Feldhusen, and K.-H. Grote, Engineering Design. London: Springer London, 2007, available: https://www.springer.com/gp/book/97818 
46283185.

[16] A. D. Aghnia, "Pemetaan Keluhan Muskuloskeletal Disorders Berdasarkan Faktor Risiko Pekerjaan Pekerja Produksi Bakso CV Unique Mandiri Perkasa Bekasi Tahun 2017," UIN Syarif Hidayatullah Jakarta: Fakultas Kedokteran dan Ilmu Kesehatan, 2017, available: http://repository.uinjkt.ac.id/dspace/handl e/123456789/35977.

[17] P. Tarwaka and L. S. Bakri, Ergonomi Industri Dasar-dasar pengetahuan ergonomi dan aplikasi di tempat kerja. Surakarta: Harapan Press, 2010, available at: Google Scholar.

[18] S. Surasno and B. Tjahjohartoto, "Rekayasa Ulang Dongkrak Rel Kereta Api Kapasitas 10 Ton," J. Teknol. Bahan dan Barang Tek., vol. 4, no. 2, p. 63, Dec. 2014, doi: 10.37209/jtbbt.v4i2.49.

[19] W. Zeiler, "Morphology in conceptual building design," Technol. Forecast. Soc. Change, vol. 126, pp. 102-115, Jan. 2018, doi: 10.1016/j.techfore.2017.06.012.

[20] D. Nursyahuddin and D. Gasni, "Proses Perancangan Sistem Mekanik dengan Pendekatan Terintegrasi: Studi Kasus Perancangan Alat Uji Pin on Disc," Teknika, vol. 21, no. 1, pp. 14-29, 2015, available at: Google Scholar.

[21] I. W. Sukania, “Aspek Ergonomi Dalam
Perbaikan Fasilitas Pembuat Cetakan Pasir di PT.X," Seminar Nasional Tahunan Teknik Mesin (SNTTM), 2010, available: http://repository.untar.ac.id/107/.

[22] T. K. Acharyaa" "Material handling and process improvement using lean manufacturing principle"," Int. J. Ind. Eng., vol. 18, no. 7, pp. 357-368, 2011, available:

https://journals.sfu.ca/ijietap/index.php/iji e/article/view/240.

[23] M. Andriani, M. T. Hasan, Nazaruddin, and NinaFahriana" "Application of Anthropometry to Overcome Musculoskeletal Problem"," J. Phys. Conf. Ser., vol. 1114, p. 012008, Nov. 2018, doi: 10.1088/1742-6596/1114/1/012008.

[24] A. Sokhibi, M. A. Alifiana, and M. I. Ghozali, "Perancangan Troli Ergonomi pada Aktivitas Pengangkutan Beras di Penggilingan Padi," J. Sist. dan Manaj. Ind., vol. 2, no. 2, pp. 111-117, Dec. 2018, doi: 10.30656/jsmi.v2i2.840.

[25] C. Ucar and T. Bayrak" "Improving Inplant Logistics: A Case Study of a Washing Machine Manufacturing Facility"," Int. J. Ind. Eng., vol. 22, no. 2, pp. 195-222, 2015, available: https://journals.sfu.ca/ijietap/index.php/iji e/article/view/1141. 